\title{
Rock art imagery as a proxy for Holocene environmental change: A view from Shuwaymis, NW Saudi Arabia
}

\author{
Maria Guagnin,' Richard Jennings,' Heidi Eager,' \\ Ash Parton,' Christopher Stimpson,' Christian Stepanek, ${ }^{3}$ \\ Madlene Pfeiffer, ${ }^{3}$ Huw S. Groucutt,' Nick A. Drake, ${ }^{2}$ \\ Abdullah Alsharekh ${ }^{4}$ and Michael D. Petraglia'
}

\begin{abstract}
The animal species depicted in the rock art of Shuwaymis, Saudi Arabia, provide a record of Holocene climatic changes, as seen by the engravers. Of 1903 animal engravings, I5I4 contained sufficient detail to allow identification with confidence. In addition, the stratigraphy of the engravings and the depiction of domesticates provide a broad chronological framework that allows a division into images created during the Holocene humid phase and animals represented after the onset of desert conditions. Despite the large sample size, only 16 animal species could be identified, which represents an extraordinarily narrow species spectrum. Comparison with the scarce faunal record of the Arabian Peninsula shows that all larger animals that are thought to have been present in the area were also depicted in the rock art. The contemporaneous presence of at least four large carnivores during the Holocene humid phase suggests that prey animals were abundant, and that the landscape consisted of a mosaic of habitats, potentially with thicker vegetation along the water courses of the wadis and more open vegetation in the landscape around them. Community Earth System Models (COSMOS) climate simulations show that Shuwaymis was at the northern edge of the African Summer Monsoon rainfall regime. It is therefore possible that Shuwaymis was ecologically connected with southwestern Arabia, and that an arid barrier remained in place to the north, restricting the dispersal of Levantine species into Arabia.
\end{abstract}

\section{Keywords}

Arabian Peninsula, climate simulation, Holocene environment, human-environment interaction, prey biomass, rock art

Received 22 December 2015; revised manuscript accepted 23 February 2016

\section{Introduction}

Animal depictions feature prominently in rock art around the world and offer a unique perspective on the cultural traditions and ecological settings of past societies. Animals convey important information about prehistoric environments because they have particular habitat requirements that vary between species. Where multiple depictions of different animal species can be identified within a single rock art phase, a complex picture of the environment of the engravers can emerge. Particularly in areas where the environment has undergone a climatic shift, such as the midHolocene of northern Arabia, animal imagery can be an indicator of associated habitat changes. Depictions of savannah or desert animals have been linked to past environments since the beginning of rock art research in the 19th century (see, for example, Barth, 1857; Horsfield et al., 1933; Muzzolini, 1992; Rollefson et al., 2008). However, while the image repertoire is driven by the engravers' experiences of their environment, it is important to acknowledge that it can only be seen through the cultural filter of the engravers' choice to depict specific animals (Guagnin, 2014).

During the early Holocene humid phase, the landscapes of Arabia comprised a dramatically ameliorated environment, featuring lakes, wetlands and the expansion of vegetation. In the northwest of the Arabian Peninsula, Holocene lake sediments have been reported from the oasis towns of Tayma and Jubbah, indicating that lake formation occurred as early as $10,000 \mathrm{BC}$ (Crassard et al., 2013; Engel et al., 2012; Hilbert et al., 2014; see also Dinies et al., 2015). This is in contrast to the Nefud desert where no Holocene lake deposits have so far been identified (Rosenberg et al., 2013). By the beginning of the fourth millennium $\mathrm{BC}$, palaeoenvironmental records indicate a widespread increase in aridity across much of Arabia (e.g. Magee, 2014: 85; Parker et al., 2006; Preston et al., 2012).

While the Holocene archaeology of the area remains poorly known, abundant rock art and large numbers of cairns and other

\footnotetext{
'Research Laboratory for Archaeology and the History of Art, University of Oxford, UK

2Department of Geography, King's College London, UK

${ }^{3}$ Alfred Wegener Institute, Helmholtz Centre for Polar and Marine Research, Germany

${ }^{4}$ Department of Archaeology, King Saud University, Saudi Arabia
}

\section{Corresponding author:}

Maria Guagnin, Research Laboratory for Archaeology and the History of Art, University of Oxford, Hayes House, 75 George Street, Oxford OXI 2BQ, UK.

Email: maria.guagnin@rlaha.ox.ac.uk 
structures indicate extensive prehistoric occupations. From localities such as Jubbah sparse Epipalaeolithic, Neolithic and possibly Chalcolithic stone tool assemblages have been identified (Crassard et al., 2013; Garrard et al., 1981; Hilbert et al., 2014; Parr et al., 1978). However, no faunal remains of this date have been retrieved or analysed in the region. Our understanding of the environmental prehistory is, therefore, predominantly based on early Holocene lake sediments from the Tayma and Jubbah oases, along with the extrapolation of wider Levantine and Arabian climatic patterns. The nature of environments outside the oases, the types of animal species they supported and whether humans occupied them remain largely unknown.

The range of fauna represented in the rock art of Shuwaymis, northwestern Saudi Arabia, provides compelling evidence that humans and animals once thrived in landscapes that are extremely arid today. Analyses of the stratigraphic relationship between hunter and herder imagery indicate that local hunters adopted cattle herding (Guagnin et al., 2015). Using the transition to cattle herding in the seventh millennium $\mathrm{BC}$ and the introduction of domestic camel and horses in the first and late second millennium BC as chronological markers (see, for example, Drechsler, 2007, 2009; Grigson, 2012; Magee, 2014; Uerpmann and Uerpmann, 2012), the rock art can be divided into engravings relating to humid and arid environments. This allows an analysis of the species spectrum across the Holocene climatic sequence and also opens up wider questions: Does the species range observed in the rock art fit with current hypotheses on environmental change in the Arabian Peninsula during the Holocene? Can the animal engravings give us an indication of local habitats and vegetation in the absence of faunal remains?

In addition to evidence from the rock art, we use climate data simulated by the Community Earth System Models (COSMOS) to explore the intensity and timing of rainfall regimes in the area. This combined approach will not only increase our understanding of local environmental and habitat changes during the Holocene but also aims to identify whether the environments identifiable at Shuwaymis were linked to Levantine or southern Arabian climate regimes, and ultimately provide information of the movement and connectivity of human and animal populations.

\section{Background}

\section{Archaeology}

The prehistoric archaeological record of Arabia, and how it correlates with environmental and ecological changes, remains poorly understood, but has become a focus of increased research in recent years (e.g. Crassard and Drechsler, 2013; Groucutt and Petraglia, 2012; Petraglia et al., 2015; Petraglia and Rose, 2009). In the case of the Holocene, processes of demographic and behavioural change - such as 'Neolithisation' - are the subject of ongoing debate. Unlike the Neolithic in the Levant, the transition from hunting and gathering to food producing economies in Arabia centred on mobile herding rather than sedentism or crop cultivation (Magee, 2014; McCorriston and Martin, 2009). The few faunal remains that have been radiocarbon dated come from sites along the eastern and southern fringes of the peninsula and suggest that domestic cattle, sheep and goat were introduced as a package between 6800 and 6200 BC (Drechsler, 2007, 2009). Because their domestication in the Levant predates their earliest known occurrence on the Arabian Peninsula, they are assumed to have originated in the Levant. As a consequence, Levantine herder populations are thought to have entered the region during the peak of the Holocene humid period when grassland and vegetation expanded across the Arabian Peninsula and provided new pastures (Drechsler, 2007). However, there are no unambiguous traces of incoming populations in the lithic evidence (Crassard and Drechsler, 2013; Drechsler, 2007). The recent discovery of
el-Khiam and Helwan points similar to those from the Pre-Pottery Neolithic (PPN) at Jebel Qattar 101, at the Jubbah oasis, may provide some evidence of population movements or interactions. However, whether they are the result of Levantine populations coming to the Nefud desert or of local groups adopting Levantine lithic technologies is currently unclear (Crassard and Drechsler, 2013; see also Charpentier and Crassard, 2013; Crassard et al., 2013). In southern Arabia, early-mid-Holocene lithic technology appears to be characterised by indigenous developments (Crassard and Drechsler, 2013) and herding may have been adopted as a pioneering strategy among indigenous hunters and later developed locally into specialised pastoralism (McCorriston and Martin, 2009).

At the beginning of the fourth millennium BC, Arabia became increasingly arid. Archaeological contexts in southeastern Arabia provide a powerful narrative of the environmental pressures past societies had to negotiate. Around $3900 \mathrm{BC}$, the onset of arid conditions is thought to have caused a widespread abandonment of sites throughout southeastern Arabia. Mobile herders retreated to the Omani coast, and for about 600 years, their subsistence focussed on marine resources and domestic animals. With the onset of the Bronze Age around $3100 \mathrm{BC}$, southeast Arabia was re-settled in an expansion of oasis agriculture that was likely based on the development of early irrigation systems (Preston et al., 2012; see also Magee, 2014). How this period of climatic deterioration affected human populations in the central and northwestern areas of the Arabian Peninsula during the fourth millennium BC remains unknown. Similar to southern Arabia, the Bronze Age in the northwest was characterised by an intensification of irrigation-based agriculture. In the oasis of Tayma, a substantial settlement was established (Eichmann et al., 2006; Hausleiter, 2010). In addition to settlements, the distribution of rock art, and stone structures such as desert kites and cairns also provide evidence for nomadic lifestyles and an intensified use of the landscape that may have been based on hunting (Magee, 2014; see also Newton and Zarins, 2000). During the Iron Age, inter-regional contact and trade intensified, probably at least partly as a result of camel domestication, and the settlements in the oases of northern Arabia grew substantially (see, for example, Magee, 2014). From the early first millennium $\mathrm{BC}$, a large number of literate cultures became established in western Arabia and left their traces in countless inscriptions engraved onto rock surfaces. Remarkably, literacy was not limited to settled areas but was also widespread among nomadic peoples. In the north, these scripts fell out of use around the third century AD and were replaced by Nabatean Aramaic and later Arabic script (Macdonald, 2010).

\section{Environment}

The palaeoenvironmental history of the Arabian Peninsula during the early-mid-Holocene period is complex, with apparent spatial and temporal variability in the timing of climatic changes. Palaeoclimatic evidence for increased humidity is derived from numerous archives, including lacustrine and palustrine deposits, speleothems, fluvial/alluvial deposits and palaeosols, all of which may have responded differently to increased rainfall. In northwestern regions, the palaeoclimatic record for the early-mid-Holocene is unclear and rather ambiguous. At the town of Tayma, the onset of humidity and lake formation is reported from ca. $8000 \mathrm{BC}$, with lake contraction occurring by ca. 6500 BC (Engel et al., 2012). However, pollen from lake sediments indicate that a shallow lake formed around $7200 \mathrm{BC}$ and high lake levels were only achieved between 6700 and 6000 BC (Dinies et al., 2015). Around $250 \mathrm{~km}$ to the west in the town of Jubbah, the onset of humidity is recorded notably earlier. Hilbert et al. (2014) report a phase of lake formation from as early as ca. $10,000 \mathrm{BC}$, which was followed by a 
period of contraction at ca. $8000 \mathrm{BC}$ that coincided with human occupation of the basin. A further phase of shallow lake development is recorded at ca. $4600 \mathrm{BC}$. Additionally, Crassard et al. (2013) report the formation of a shallow lake at Jubbah at ca. 6700 BC. Pollen records from lake sediments at Tayma provide evidence for vegetation changes and indicate that grasslands spread after $7000 \mathrm{BC}$ and reached their maximum expansion between around 6600 and $6000 \mathrm{BC}$. These would have created favourable grazing conditions for animal herds. At $6000 \mathrm{BC}$, pollen records indicate an abrupt retreat of grasslands and a replacement of vegetation with more drought-resistant shrublands, which were similar to current landscapes (Dinies et al., 2015).

The widespread climatic amelioration during the Holocene is also recorded in speleothem growth in Oman and Yemen which is attributed to a northward migration and intensification of the Indian Ocean Summer Monsoon (IOSM) at ca. 8300 BC (Burns et al., 2001; Fleitmann et al., 2003, 2007, 2009). However, in southern and western reaches of the peninsula, rainfall was predominantly brought by the African Summer Monsoon (Jennings et al., 2015; Parton et al., 2015; Rosenberg et al., 2013). By ca. 5000 BC, a climatic downturn is also indicated by records in the south of the Arabian Peninsula (e.g. Lézine et al., 2007).

Ostensibly, environmental proxies have predominantly comprised lacustrine archives, but as recent studies have shown (Parton et al., 2015), in order to fully understand the range of temporal and spatial climatic variability in Arabia throughout prehistory, we must look beyond simplistic wet/dry indicators. Moreover, we must build up an understanding of how human and animal populations navigated these climatic changes. In this respect, rock art in arid regions such as Arabia is key; it provides our only visual representation of those past environments and allows us to make inferences of animal populations that must have been present in the area.

\section{Landscape}

The engravings of Shuwaymis are found along the escarpments that flank the east and west of a wadi course that stretches northward from the edge of the ancient lava fields of the Harrat Khaybar (Figure 1). The Shuwaymis rock art complex was brought to the attention of the Saudi Commission for Tourism and National Heritage (SCTH) in 2001 and is thought to contain some of the oldest engravings on the Arabian Peninsula. Preliminary field surveys quickly established the significance of the site (Al-Saud and Khan, 2005; Bednarik and Khan, 2002), and it was granted UNESCO world heritage status in 2015. Shuwaymis East, a key component of the site, was thoroughly mapped by the authors in 2013, at the request of SCTH. Using high-resolution differential GPS survey equipment, 273 rock art panels were recorded over a length of $800 \mathrm{~m}$ along a sandstone escarpment (Jennings et al., 2014). Of the 273 panels, 254 were found to contain representations of animals.

\section{Methods}

In total, 1903 individual animal depictions were identified on the panels recorded in Shuwaymis East. In order to address the difficulty arising from the identification of the images that are occasionally stylised and often reduced to stick animals, the certainty of each taxonomic determination was rated. A score between 1 and 5 was assigned to all animal identifications, where 1 indicates an uncertain identification and 5 very high confidence (Guagnin, 2014). However, species that appear identical in their outline, such as different types of gazelles (Gazella sp.) or foxes (Vulpes sp.), were grouped into genera. Onager (Equus hemionus) and African wild ass (Equus africanus) are also difficult to distinguish

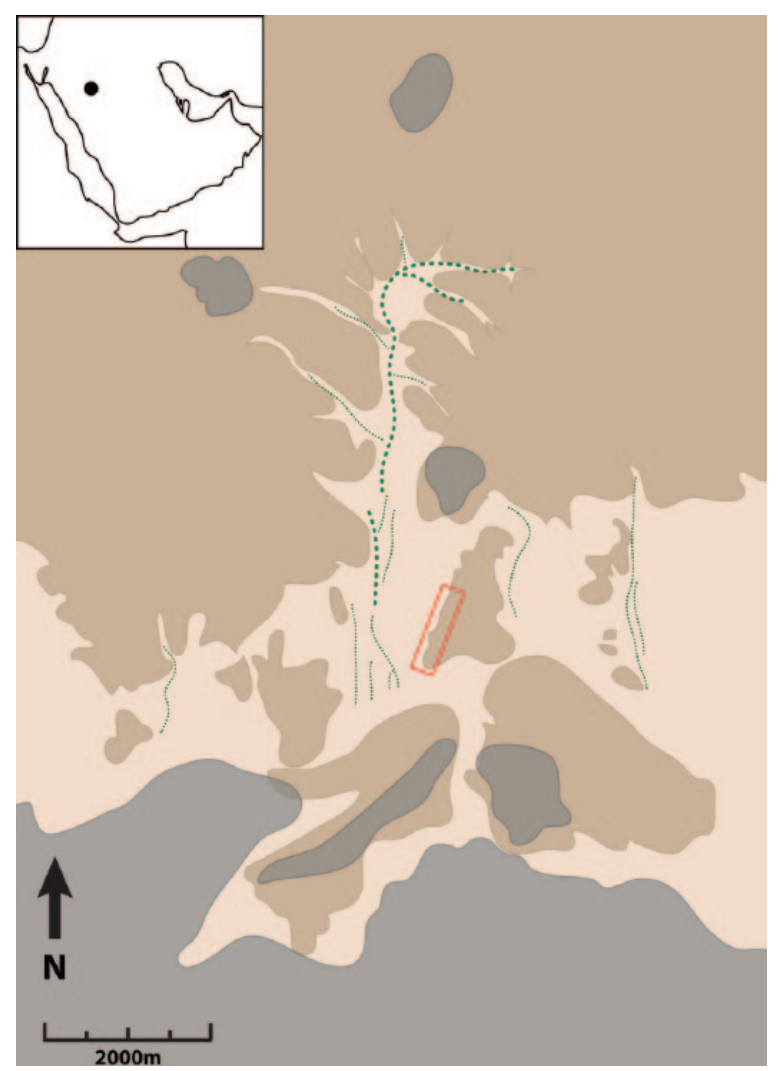

Figure I. Map showing the landscape of Shuwaymis (the surveyed area is indicated with a rectangle). Dark grey:Ancient lava fields of the Harrat Khaybar. Lighter shading: Rocky outcrops north of the Harrat Khaybar and west of the Harrat Ithnayn. Dashed:Vegetation still present in wadi courses today. The rest of the area, including the floor of the wadi along which the engravings of Shuwaymis are found, is covered in sand.

in their outline and were grouped together. In 10 of the 31 identifications, the larger head and ears suggested a depiction of African wild ass rather than onager. There is still some doubt whether the range of African wild ass extended into Western Asia (Kimura et al., 2013). While the rock art, alongside other lines of evidence, would suggest that African wild ass was present in Arabia (Fedele, 2008; Grinder et al., 2006; Olsen and Bryant, 2013; Uerpmann, 1987), the engraved outline of two such similar animal species cannot provide conclusive evidence. In total, 1514 of the depictions contained sufficient detail to allow an identification of the animal species with high or very high confidence. This constitutes $80 \%$ of all recorded animal engravings and represents an extraordinary high frequency of confident identifications. In a similar sample in the Sahara, an identification of $48 \%$ was achieved (Guagnin, 2014). This high degree of positive identification is largely a result of the naturalism of many of the depictions and a focus on characteristic features in all depicted species. For example, 210 male ibex (Capra (ibex) nubiana) with very large backward curving horns were identified with confidence in Shuwaymis East. In contrast, only four depictions show similar bovids with shorter horns, which may represent females. While there is a clear cultural bias towards the depiction of specific species and their characteristics, the high frequency of species identifications and large number of engravings make the rock art recorded at Shuwaymis East a robust sample for ecological analyses.

The representation of animals in the rock art is not a direct indication of environmental conditions, but is heavily influenced by the engravers' cultural background, artistic choice and individual experience (Guagnin, 2014). The high degree of realism in the animal engravings of Shuwaymis and the absence of 


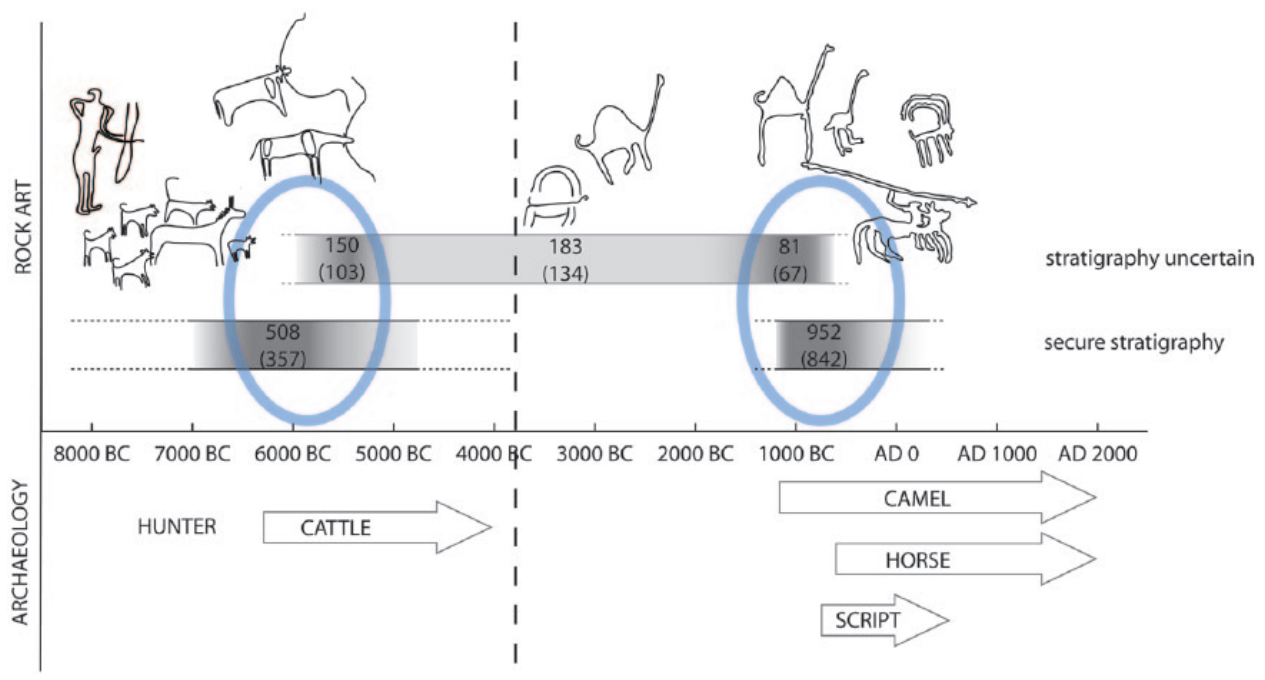

Figure 2. Tentative chronological distribution of all 1903 animal engravings (identifiable species in brackets). In 29 engravings (9), erosion was too advanced to identify stratigraphy or age. Dark shading indicates high frequency of engravings. Dashed line indicates the approximate timing of the onset of arid conditions. Arrows indicate the introduction and presence of domestic animals and script.

anatomical errors suggest that the engravers were highly familiar with the depicted species and had direct knowledge of them. Transhumance patterns of herders in similar environments in North Africa have been shown to extend over distances of ca. $200 \mathrm{~km}$, with routes following a length of close to $500 \mathrm{~km}$ (Smith, 2005: 6). The sighting of animals is therefore likely to have been limited to a localised area. Similar studies in the Sahara have shown that rock art tends to reflect animals that are present in the vicinity of the engraving (Guagnin, 2014).

The main discrepancy between environmental and cultural records lies in the frequency with which each animal species is depicted. Comparison between rock art and faunal remains in the Negev and in the Badia of eastern Jordan have shown that although the rock art is characterised by a dominance of ibex and very few depictions of gazelles, osteological evidence indicates that gazelle was the most hunted animal (Eisenberg-Degen and Rosen, 2013; Rollefson et al., 2008). Analyses of rock art in the central Sahara have shown that while smaller animals such as reptiles, birds and rodents are scarce in the rock art, representation of animals with a body weight of over $10 \mathrm{~kg}$ captures the complete spectrum of species identified in the faunal record. However, the majority of engravings depict animals that were of symbolic, cultural or economic importance (Guagnin, 2014). As a consequence, environmental interpretation of animal engravings has to be based on large sample sizes, and the presence of animals, rather than their frequency.

Three steps were followed in our ecological analysis of rock art at Shuwaymis. In the first, the species spectrum and frequency of securely identified animal engravings were analysed over time. Chronometric dating of rock art is difficult and as yet no direct dating methods exist that can be applied to a large body of engravings. The engravings of Shuwaymis have therefore been grouped into a relative chronology that hinges on the transition from hunting to herding at one end and on the introduction of domestic camel and horse at the other. Using the stratigraphy and relative degree of weathering of the engravings of each panel, a group of early (hunter/herder) rock art and a group of late (camel/horse) rock art were identified (Figure 2). However, patina formation and weathering are not uniform at Shuwaymis (Guagnin et al., 2015) and not all panels have a stratigraphic sequence of engravings. Engravings that could not be attributed to either phase with certainty were classed into a middle category. As a result, this middle category contains some engravings that belong to the end of the early phase and some that belong to the beginning of the late phase. The long time span assigned to the middle category, and the relatively low number of engravings that are not associated with the early or late period, indicates that the rock art was largely created around introduction of domesticates: cattle and camel/horse.

This broadly matches the chronology proposed by Khan (2007) who dated the creation of the rock art of Shuwaymis to the early Neolithic, followed by a hiatus and the resumption of engraving activity with depictions of camel, which he attributes to the Bronze Age. Although the length of time between the two periods at Shuwaymis is uncertain, both phases are separated by an extensive rock fall episode after which the fallen and inverted panels of the early phase were often re-engraved in the later phase (Jennings et al., 2014). This rock fall may have been caused by tectonic activity (Bednarik and Khan, 2002) or increasing daily temperature contrasts associated with the onset of desert conditions (Cremaschi, 1998: 28).

The primary aim of this broad chronological framework was to enable an analysis of the species spectrum across different phases of rock art creation that correlate with climatic periods. While the early rock art was created during the Holocene humid period, the late phase post dates the onset of severe aridification and relates to a time of absolute desertification.

In the second step, the animal repertoire identified in the rock art is compared with the Holocene faunal record of the Arabian Peninsula and the wider region of Western Asia. Although prehistoric faunal remains are still unknown in the region around Shuwaymis and remain scarce in the rest of the Arabian Peninsula, this comparison enables us to estimate the extent to which the engraved faunal record matches the animals present in the Holocene environment. Using biomass estimates for the prey species of carnivores we can then gain an understanding of the size of the animal populations in the Holocene landscapes of Shuwaymis. Moreover, this comparison highlights any species that are absent in the pictorial record but would have been expected in the types of habitats projected for the area around Shuwaymis.

In the third and final step, we study data derived with a climate model in order to understand the types of rainfall regime that evolved in the Holocene around $6000 \mathrm{BC}$, and to explore possibilities of ecological connectivity between Shuwaymis and the wider region. The climate model toolbox selected for the study is the COSMOS that are based on a coupled atmosphereocean general circulation model as described by Stepanek and 
Table I. Parameters of simulations of pre-industrial (PI) and mid-Holocene (6000 BC, HOL6) climate, including the specification of the total integration time of the simulation (sim., model years) and the averaging period (avg., model years).

\begin{tabular}{|c|c|c|c|c|c|c|c|c|c|}
\hline & \multirow[t]{2}{*}{ Time reference } & \multicolumn{3}{|c|}{ Orbital forcing } & \multicolumn{3}{|l|}{ Trace gases } & \multicolumn{2}{|c|}{ Time period } \\
\hline & & ecc & obl $\left({ }^{\circ}\right)$ & $\operatorname{lonp}\left({ }^{\circ}\right)$ & $\mathrm{CO}_{2}$ (ppmv) & $\mathrm{CH}_{4}$ (ppbv) & $\mathrm{N}_{2} \mathrm{O}$ (ppbv) & sim. & avg. \\
\hline $\mathrm{PI}$ & AD 1850 & 0.0167 & 23.45 & 282.2 & 280 & 760 & 270 & 3000 & 50 \\
\hline HOL6 & $6000 \mathrm{BC}$ & 0.0191 & 24.209 & 148.6 & 278 & 650 & 270 & 500 & 50 \\
\hline
\end{tabular}

Abbreviations of orbital forcing parameters stand for ecc - eccentricity of the Earth's Orbit around the sun; obl - Earth's axial tilt (angle between rotational axis and orbital axis); lonp - length of the perihelion with respect to the vernal equinox.

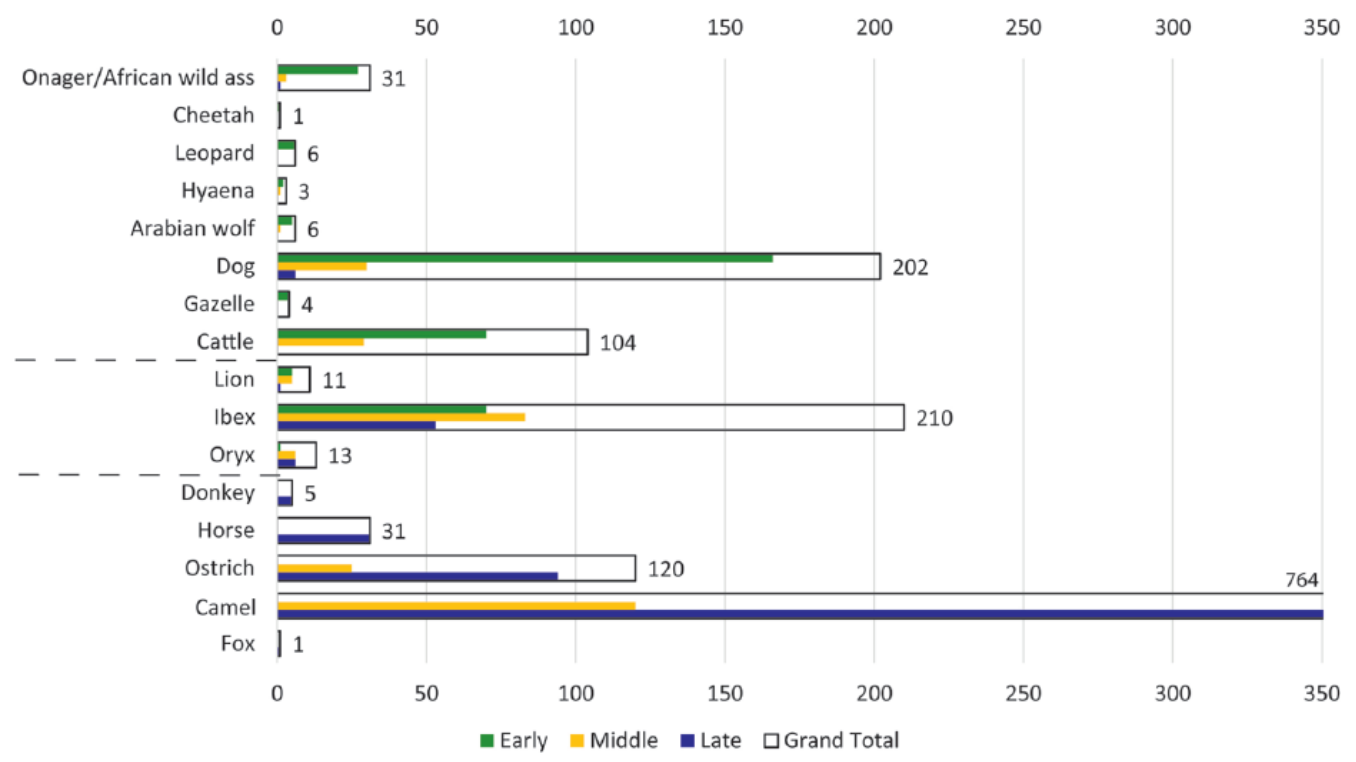

Figure 3. Graph listing the total number of confident identifications for each species or genus; occurrence across early, middle and late engraving periods is indicated by the grouped light, medium and dark shaded columns within the total. Dashed lines indicate changes between animals predominantly present in early, middle and late engraving periods. Numbers for camels were capped at 350 to retain the visibility of species with few identifications.

Lohmann (2012). The climatic data modelled with COSMOS are taken from a simulation that is similar to simulation HOL-x 0.5 of the supplementary material of Pfeiffer and Lohmann (2015), but considers in contrast a Greenland Ice Sheet of present-day extent and height and orbital forcing that is corresponding to $6000 \mathrm{BC}$; the latter has been derived based on the solution of orbital parameters by Berger (1978). Of the various simulated climate characteristics, only the climate variable total precipitation, defined as the sum of large-scale and convective precipitation, is analysed in this study. The climatic data are derived in the form of time series of global coverage at the end of time slice equilibrium simulations. This means that internal variability as modelled in the coupled atmosphere-ocean-land climate system is explicitly included in the time series data, but no external variability (e.g. varying concentrations of astronomical parameters or infrared-active trace gases) imprints on the climate state. Each analysed time series covers a time period of 50 model years, which are comparable with real calendar years. Average monthly and yearly precipitation values were generated over this time period of 50 model years from two simulations: One climate simulation (HOL6) is representative for the period of $6000 \mathrm{BC}$, which coincides with the later part of the Holocene humid phase. A second climate simulation (pre-industrial (PI), refer to Pfeiffer and Lohmann (2015) for details) is representative for the preindustrial period, which serves as a good analogy for an aridification phase, as the climate of Arabia today is broadly similar to the climate that followed the Holocene humid phase in the fourth millennium BC. Details of parameters and configuration of the climate simulations are summarised in Table 1.

\section{Results}

\section{Species spectrum}

Despite the large sample size and high rate of confident animal identifications, only 16 animal species could be identified in the rock art of Shuwaymis (Figure 3). This pattern is partly the result of a culturally driven omission of smaller animals with a body weight below ca. $10-15 \mathrm{~kg}$ in the depictions. However, compared with similar bodies of rock art in North Africa, this represents an extraordinarily narrow species spectrum (Guagnin, 2014; see also Le Quellec, 1998; Vernet, 1995). The rock art is dominated by a small number of frequently depicted animals (746 camels, 210 ibex, 202 dogs, 120 ostriches and 104 cattle). Ibex are depicted throughout all phases of rock art creation at Shuwaymis and may have been a symbol of religious activity; for the pre-Islamic periods, ritual ibex hunts are attested in South Arabian inscriptions (Maraqten, 2015; Serjeant, 1976: 84). Engravings of ostrich are also very common and are often depicted in association with domestic camels (out of 49 panels containing ostrich depictions, 44 showed an association with domestic camels). With the exception of ibex and ostrich, all frequently depicted species are domesticates and as such clearly had considerable economic value.

Against the background of the Holocene humid phase, it is surprising that all identified wild animals are adapted to arid or even desert conditions and were widespread in Arabia until at least the 19th century (Cooper et al., 2009; Harrison and Bates, 1991; IUCN, 2015). Moreover, all depicted domesticates can be raised in reasonably arid conditions. Horse and donkey have been used for travel and transport across deserts since their domestication (Förster, 
2007; Macdonald, 2012; Mattingly, 2006) and camels were probably domesticated because of their adaptation to desert conditions (see, for example, Magee, 2014). The only individual species providing an indication of a wetter environment comes from the presence of cattle herding, which is not practised under current climatic conditions. Cattle need to be watered every second day and also require sufficient pasture. However, traditional cattle pastoralism, by definition, is confined to areas with less than $400 \mathrm{~mm}$ of annual rainfall to avoid competition with agriculture (Otte and Chilonda, 2002).

Figure 3 also shows the frequency with which each animal species is depicted across the three identified rock art periods. Although the middle period predominantly contains engravings without stratigraphic context (see above), a distinct change is visible in the species depicted during the early and late periods. The early engraving period contains a wide range of wild animals (onager/African wild ass, cheetah, leopard, hyena, Arabian wolf, gazelle, lion and ibex) as well as domestic hunting dogs and cattle. With the exception of lion, ibex and oryx, which are present throughout the creation of rock art in Shuwaymis, the depiction of wild animals ceases in the later phase and the rock art becomes dominated by depictions of desert-adapted domesticates (camel, horse and donkey) and ostrich. Depictions of cattle are completely absent in the later engraving period, which indicates that the shift to aridity may have made cattle herding impossible in this region. While the individual species identified at Shuwaymis do not provide an indication for wetter climate, the species spectrum captured in the early and late engraving periods reflects a distinct change in the landscape around Shuwaymis that is consistent with the known changes of the Holocene climatic sequence.

Carnivores contribute the largest range of species to the rock art of Shuwaymis. Depictions appear to be contemporaneous during the Holocene wet phase, which suggests that the landscape around Shuwaymis provided suitable habitats and prey. Arabian wolf (Canis lupus arabs) and fox are both desert-adapted and can subsist on very small prey, such as rodents, birds and lizards (Gasperetti et al., 1985; Kingdon, 1997). While large predators such as lion (Panthera leo), leopard (Panthera pardus), cheetah (Acinonyx jubatus) and striped hyena (Hyaena hyaena) are also adaptable to arid environments, they require a substantial prey biomass (Carbone and Gittleman, 2002). Lions are adapted to a wide range of habitats and vegetation types with the exception of dense forests and deserts (Kingdon, 1997). Leopards prefer habitats where vegetation provides cover for stalking and protection from other predators. Leopards also tend to cache kills in trees to protect themselves from kleptoparasitism by competitors and scavengers (Estes, 1991; Hayward et al., 2006a, 2007; Kingdon, 1997). Cheetahs generally prefer the patchy cover of more open vegetation (Hayward et al., 2007; Kingdon, 1997). Hyenas also occupy a wide range of habitats and, although primarily scavengers, they also hunt and consume substantial biomass (Watts and Holekamp, 2007). While large mammalian predators adapt hunting behaviours and prey preferences in the face of competition from other large predators (Hayward et al., 2007), the presence of all four predators in the area around Shuwaymis does suggest that relatively small, medium and large prey animals were abundant and that the landscape consisted of a mosaic of habitats, potentially with thicker vegetations along the water courses of the wadis and more open vegetation in the landscape around them (Figure 4). Different sized prey animals are also evident in the rock art, where they range from onager and wild ass to smaller species such as ibex and gazelle. With apex predators (e.g. lion), mesopredators (e.g. fox) and herbivores depicted in the rock art, we can assume a functional community assemblage that would also have contained mammals with a body weight of less than $15 \mathrm{~kg}$, such as hyrax or hare, that are likely to have been present in the area but the engravers chose not to depict them.

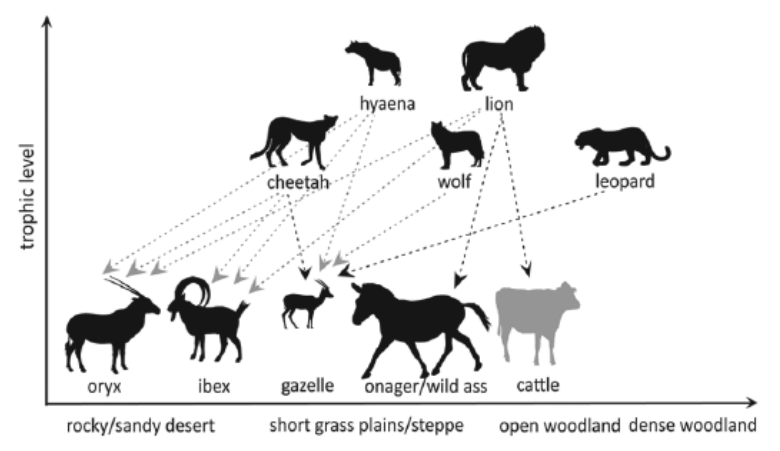

Figure 4. Habitat and prey preferences (based on mass) for a hypothetical Shuwaymis community for the early period of rock art. Preferred prey in black lines and prey taken relative to abundance in grey lines. Cattle are indicated in grey as domestic herds would have been protected by humans.

The range of styles, engraving techniques and weathering patterns visible on the carnivore engravings suggests that they were created over a longer period of time. This long-term persistence of large carnivores over the early period of the rock art, and in the case of lions, into the late period, suggests stable populations of species over these periods. The minimum viable population (the minimum population size required for a species to probabilistically persist over a given length of time) estimated for lions to persist for 40 generations (approximately 280 years - based on a generation time of 6.98 years (IUCN, 2015)) is 5792 sexually mature adults (Reed et al., 2003). This indicates landscapes suitable for lions were available outside Shuwaymis and that they were connected via corridors to allow immigration and emigration of individuals within the metapopulation.

\section{Comparison with faunal record}

The animals identified in the rock art of Shuwaymis and the species believed to have been present in the area during the Holocene are broadly comparable. It appears that all larger animals present in the area were chosen for depiction (Table 2). The comparison with the faunal record therefore suggests that the narrow species spectrum was not a cultural choice but a reflection of the local fauna.

The close correlation between the species spectrum in the rock art and in the faunal remains also allows a reconstruction of predator and prey patterns in the prehistoric landscapes around Shuwaymis. Predation is linked to the age structure of prey so that adults are targeted up to a point relative to their mass, and juveniles are targeted when energetically efficient. Here, we estimate resource abundance based on adult prey mass (Figure 5).

Lions prefer prey with a body mass between 92 and $632 \mathrm{~kg}$, while prey with a weight of $32-92 \mathrm{~kg}$ is taken relative to abundance (Clements et al., 2014; see also Hayward et al., 2007; Hayward and Kerley, 2005; Kingdon, 1997). Leopards are solitary predators and mostly prey on smaller animals with $15-45 \mathrm{~kg}$ preferred body mass, animals with less than $15 \mathrm{~kg}$ are taken relative to abundance. (Clements et al., 2014; Hayward et al., 2006a, 2007). Cheetahs prey on small to medium ungulates with 14 $40 \mathrm{~kg}$ preferred body mass and up to $135 \mathrm{~kg}$ taken relative to abundance (Clements et al., 2014; see also Hayward et al., 2007). Although hyenas are primarily scavengers, they also hunt; their preferred prey has a body mass of 91-139 kg, and animals down to $15 \mathrm{~kg}$ are taken relative to abundance (estimates for the spotted hyena (Crocuta crocuta), which has a similar diet to the striped hyena (Watts and Holekamp, 2007)).

In terms of potential wild prey animals for large felids, of the depicted ungulates, only onager/wild ass falls in the weight range of the lion's preferred prey (see Hayward et al., 2007; Hayward 
Table 2. Comparison between species identified in the rock art and faunal record of the Arabian Peninsula and the Levant. a: Barnett et al., 20I4; b: Cooper et al., 2009; c: Curci et al., 20I4; d: Drechsler, 2007; e: Fedele, 2008; f: Gasperetti et al., I985; g: Grinder et al., 2006; h: Harrison and Bates, I99I; i: Kimura et al., 20 I3; j: Magee, 20I4; k: McCorriston and Martin, 2009; I: Olsen and Bryant, 20l3; m: Robinson and Matthee, 1999; n: Uerpmann, I987; o: Uerpmann and Uerpmann, 20I2; p:Winney et al., 2004; q: IUCN, 20 I5; r: Evidence scarce but presence generally assumed, although Kimura et al. (2013) doubt presence of Equus africanus in Western Asia; s: species not yet described. *Animal outside weight range of animals usually chosen for depiction but representation of species not distinguishable from larger species within the Genus.

\begin{tabular}{|c|c|c|c|c|}
\hline & Shuwaymis rock art & $\begin{array}{l}\text { Present around } \\
\text { Shuwaymis }\end{array}$ & $\begin{array}{l}\text { Elsewhere on the Arabian } \\
\text { Peninsula }\end{array}$ & Fertile Crescent \\
\hline \multicolumn{5}{|l|}{ Equidae } \\
\hline Onager (Equus hemionus) & $x$ & $x^{9}$ & $X^{e, q}$ & $X^{n, q}$ \\
\hline Wild ass (Equus africanus) & $x$ & $X ! g, l, n, r$ & $X ?$ e,g,l,n,r & Levant?g,l,n,r \\
\hline Wild horse (Equus ferus) & & & & $x^{n}$ \\
\hline Domestic donkey (Equus africanus asinus) & $x$ & $x$ & $x$ & $x$ \\
\hline Domestic horse (Ëquus ferus caballus) & $x$ & $x$ & $x$ & $x$ \\
\hline \multicolumn{5}{|l|}{ Artiodactyla } \\
\hline Wild camel (Camelus ?o,s) & ? & $?$ & UAE and Oman ${ }^{n, o, s} Y_{e m e n} \mathrm{c}$ & $?$ \\
\hline Domestic camel (Camelus dromedarius) & $X$ (late) & $x$ & $x$ & $x$ \\
\hline \multicolumn{5}{|l|}{ Bovidae } \\
\hline \multicolumn{5}{|l|}{ Bovinae } \\
\hline Aurochs (Bos primigenius) & & & UAE and Yemene,k & $X^{n}$ \\
\hline Domestic cattle (Bos taurus) & $x$ & $?$ & East and south d,e & $x$ \\
\hline \multicolumn{5}{|l|}{ Caprinae } \\
\hline Ibex (Capra ibex nubiana) & $x$ & $X^{h}$ & $X^{h}$ & $X^{h}$ \\
\hline Wild goat (Capra aegagrus) & & & $U A E^{h}$ & $x^{n}$ \\
\hline Wild sheep (Ovis ammon) & & & UAE/Oman?h & $x^{n}$ \\
\hline Arabian Thar (Arabitragus jayakari) & & & UAE/Oman ${ }^{h, n}$ & \\
\hline Domestic goat (Capra aegagrus hircus) & & ? & East and south ${ }^{d}$ & $x$ \\
\hline Domestic sheep (Ovis aries) & & $?$ & East and south ${ }^{d}$ & $x$ \\
\hline \multicolumn{5}{|l|}{ Hippotraginae } \\
\hline Arabian oryx (Oryx leucoryx) & $x$ & $X^{h}$ & $X^{h, n}$ & $X^{h, n}$ \\
\hline \multicolumn{5}{|l|}{ Cervidae } \\
\hline Mesopotamican fallow deer (Dama mesopotamica) & & & & $X^{\mathrm{h}, \mathrm{n}}$ \\
\hline Roe deer (Capreolus capreolus) & & & & $X^{\mathrm{h}, \mathrm{n}}$ \\
\hline Red deer (Cervus elaphus) & & & & $x^{n}$ \\
\hline \multicolumn{5}{|l|}{ Antilopinae } \\
\hline Mountain gazelle (Gazella gazella) & $X(s p)$ & $X^{h}$ & $X^{\mathrm{h}, \mathrm{n}}$ & Levant ${ }^{\mathrm{h}, \mathrm{n}}$ \\
\hline Queen of Sheba's gazelle (Gazella bilkis) & $X(s p)$ & & Yemen ${ }^{\mathrm{h}}$ & \\
\hline Goitered gazelle (Gazella subgutturosa) & $X(s p)$ & $X^{h}$ & $X^{h, n}$ & $X^{h, n}$ \\
\hline Dorcas gazelle (Gazella dorcas) & $X(s p)$ & $X^{h}$ & $X^{h}$ & $X^{\mathrm{h}, \mathrm{n}}$ \\
\hline Hartebeest (Alcelaphus buselaphus) & & & & Levant ${ }^{m}$ \\
\hline \multicolumn{5}{|l|}{ Carnivora } \\
\hline \multicolumn{5}{|l|}{ Felidae } \\
\hline Cheetah (Acinonyx jubatus) & $x$ & $X^{c, h}$ & $X^{c, h}$ & $X^{c, h}$ \\
\hline Lion (Panthera leo) & $x$ & $X^{a}$ & $\mathrm{X}^{\mathrm{a}}$ & $\mathrm{X}^{\mathrm{a}}$ \\
\hline Leopard (Panthera pardus) & $x$ & $X^{c, h}$ & $X^{c, h}$ & $X^{h}$ \\
\hline \multicolumn{5}{|l|}{ Hyaenidae } \\
\hline Striped hyena (Hyaena hyaena) & $x$ & $X^{c, h}$ & $X^{c, h}$ & $X^{h}$ \\
\hline \multicolumn{5}{|l|}{ Canidae } \\
\hline Golden jackal (Canis aureus) & ? & $x^{c}$ & $X^{c, h}$ & $X^{c, h}$ \\
\hline Arabian wolf (Canis lupus arabs) & $x$ & $X^{c, h}$ & $X^{c, h}$ & $X^{h}$ \\
\hline Domestic dog (Canis lupus familiaris) & $x$ & $?$ & $x$ & $x$ \\
\hline Blanford's fox (Vulpes cana)* & $X(s p)$ & & Isolated east and south ${ }^{h}$ & $X^{h}$ \\
\hline Rueppell's fox (Vulpes rueppelli)* & $X(s p)$ & $X^{c, h}$ & $X^{c, h}$ & $X^{h}$ \\
\hline Red fox (Vulpes vulpes) & $X(s p)$ & $X^{c, h}$ & $X^{c, h}$ & $X^{h}$ \\
\hline \multicolumn{5}{|l|}{ Ursidae } \\
\hline Brown bear (Ursus arctos) & & & & $X^{h}$ \\
\hline \multicolumn{5}{|l|}{ Primates } \\
\hline Hamadryas baboon (Papio hamadryas) & & & Southwest ${ }^{\mathrm{P}}$ & \\
\hline \multicolumn{5}{|l|}{ Suidae } \\
\hline Wild boar (Sus scrofa) & & & & $X^{h, n}$ \\
\hline \multicolumn{5}{|l|}{ Hippopotamidae } \\
\hline Hippopotamus (Hippopotamus amphibus) & & & & Levant $^{n}$ \\
\hline \multicolumn{5}{|l|}{ Birds } \\
\hline Ostrich (Struthio camelus) & $x$ & $X^{b, m}$ & North and south ${ }^{\mathrm{b}, \mathrm{m}}$ & $X^{b, m}$ \\
\hline
\end{tabular}




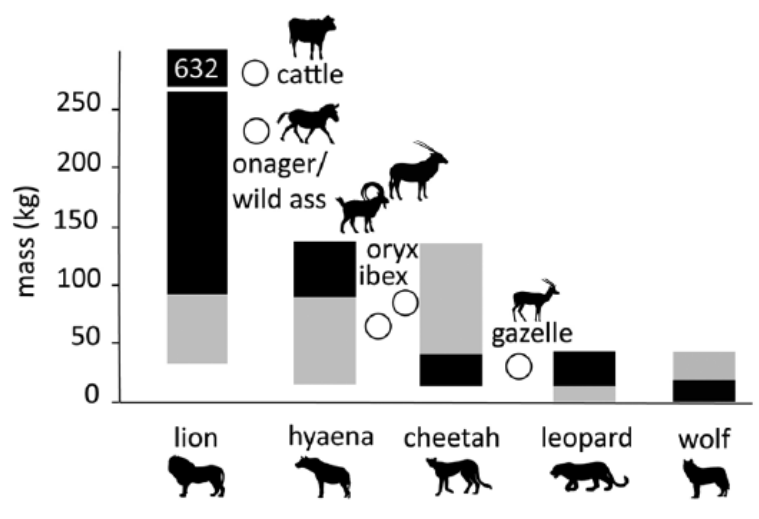

Figure 5. Carnivore preferred prey mass (black bars) and predation relative to abundance mass (grey bars), and herbivore mean mass (open circles).

and Kerley, 2005). While lions also commonly take smaller prey such as gazelle and ostrich, studies of lion prey preferences show that these species are killed less frequently than would be expected based on their availability (Hayward and Kerley, 2005). The continued depiction of lion in the rock art suggests that they were present in the area during most of the Holocene. A pride of lions is usually sedentary and typically consists of about 13 individuals (Estes, 1991; Kingdon, 1997). Based on carnivore density and prey biomass estimates of 3.4 lions per $10,000 \mathrm{~kg}$ of prey biomass (Carbone and Gittleman, 2002; see also Hatton et al., 2015), a typical pride of lions would have required over $38,000 \mathrm{~kg}$ of prey or approximately 166 onager/139 wild ass in the area. Cattle also fall in the range of lion's preferred prey and predation of livestock may well have been a source of human-carnivore conflict.

Leopards have a very broad diet but generally prefer prey with a body mass below their own. They also tend to kill animals that live in dense vegetation where they can be more easily stalked. In addition, leopards often kill smaller competitors such as cheetah (Hayward et al., 2006a) or dogs (Estes, 1991). Based on the species spectrum identified in the rock art, gazelles, smaller ibex, as well as cheetah or domestic dog fall in the preferred weight range of leopard prey. In particular, mountain gazelles, which prefer open habitat with light forest (Wildscreen Arkive, 2015), may have been a suitable prey species for leopards in the area. Based on a carnivore density of 6.17 per $10,000 \mathrm{~kg}$ of prey (Carbone and Gittleman, 2002), a single leopard would have required a biomass equivalent to 72 mountain gazelles or 56 goitered gazelles. The habitat requirements of Dorcas gazelles do not overlap with the leopard (Kingdon, 1997), and they are less likely to have been among their preferred prey.

Cheetah usually occur solitary or in small coalitions. They particularly prey on species that inhabit open grasslands and select for abundance rather than body mass alone (Hayward et al., 2006b). Gazelles as well as ibex fall within their preferred prey weight range, although studies of cheetah prey show a clear preference for gazelles (Hayward et al., 2006b). In addition, cheetah could have preyed on young animals such as the fawns of oryx, onager or wild ass. Based on Carbone and Gittleman's estimates, a single cheetah requires a prey biomass of about $4367 \mathrm{~kg}$ (Carbone and Gittleman, 2002). That is the equivalent of 93 ibex or 151 goitered gazelles. However, other population density estimates predict even higher prey requirements for leopard and cheetah (Hayward et al., 2007). While the mid-Holocene environment of Shuwaymis did not have a wide range of prey within the preferred weight range of the depicted large cats, hunting may have been more opportunistic. However, the combined preferences of lion, leopard and cheetah for specific prey sizes and species indicate that gazelles and equids were probably abundant around Shuwaymis during the Holocene humid phase, in addition to smaller mammals such as hares, hyrax and birds. In particular, the assumed abundance of gazelles is striking, as they are rare in the rock art. This highlights the cultural filter that influenced the frequency of the depictions and shows that prehistoric animal communities can only be estimated using a holistic approach.

However, the species spectrum also raises some questions. In the context of an ecosystem in which animals adapted to arid conditions thrived, the absence of wild camel and ostrich during the early rock art period is surprising. While there is evidence that both species were present in some areas of the Arabian Peninsula (Cooper et al., 2009; Robinson and Matthee, 1999; Uerpmann and Uerpmann, 2012), their distribution during the Holocene is not yet known.

The faunal remains listed in Table 2 also include a number of large animal species that were present in the Levant, such as deer, aurochs, hartebeest, wild boar and hippo. While hippo, deer and wild boar require woodland vegetation or water bodies, hartebeest and aurochs are adapted to savannah environments, and during the Holocene wet phase, their distribution included the central Sahara (Guagnin, 2014; Le Quellec, 1998; Lutz and Lutz, 1995). While a single depiction of an aurochs is known from Kilwa, on the northern edge of the Nefud desert (Guagnin et al., 2015; Horsfield et al., 1933), none were observed in Shuwaymis East. Moreover, the Neolithic pastoralists of the Negev as well as southern and eastern Jordan specialised in caprine herding (EisenbergDegen and Rosen, 2013; Henry et al., 2003; Rollefson et al., 2014). It is therefore surprising that no sheep or goat were identified in Shuwaymis.

\section{Climate modelling}

The climate data simulated by COSMOS indicate a substantial increase in rainfall levels at $6000 \mathrm{BC}$ (Figure 6). Given that an increase in humidity is recorded in the lake sediments of Jubbah and Tayma at 10,000 BC and $8000 \mathrm{BC}$, respectively (Engel et al., 2012; Hilbert et al., 2014), and pollen records indicate high lake levels between 6700 and $6000 \mathrm{BC}$ (Dinies et al., 2015), it is probable that this time slice is representative of a period of increased humidity in Arabia that extended back over 2000 years. This pattern also corresponds with the African Humid Period, where palaeohydrological data show an increase in lake records between 9500 and 5500 BC (Lézine et al., 2011; see also deMenocal and Tierney, 2012).

Moreover, the climate simulations in Figure 6 show that rainfall at Shuwaymis derived from the northward advance of the African Summer monsoon, which arrived in July, August and September (see also Jennings et al., 2015; Parton et al., 2015; Rosenberg et al., 2013). The simulations do not give any indication that Mediterranean winter westerlies reached Shuwaymis 8000 years ago, as they were less pronounced than today. Peaks in summer rainfall in western Arabia therefore coincided with low winter rainfall amounts in the Levant. In the HOL6 simulation, annual rainfall averages around $177 \mathrm{~mm}$ (Figure 7). Modelling of the aridification phase using the PI simulation shows that rainfall levels fell significantly after the end of the Holocene humid phase and average around $33 \mathrm{~mm} / \mathrm{yr}$. The climate modelled in the PI simulation therefore shows that Shuwaymis is recently considerably more arid than at $6000 \mathrm{BC}$.

The climate simulation also indicates that rainfall at Shuwaymis varied from year to year (Figure 7), as it does at present. In the HOL6 simulation, annual rainfall ranges from a low of $20 \mathrm{~mm}$ through to a high of $420 \mathrm{~mm}$ per model year. During 16 of the modelled years, the area around Shuwaymis is estimated to have received less than $100 \mathrm{~mm}$ of annual rainfall. However, 19 years simulate more than $200 \mathrm{~mm}$ of rainfall, and 10 years more than $300 \mathrm{~mm}$. In the PI simulation, 2 years reach a maximum of $140 \mathrm{~mm} / \mathrm{yr}$, with all other years receiving less than $100 \mathrm{~mm} / \mathrm{yr}$. 


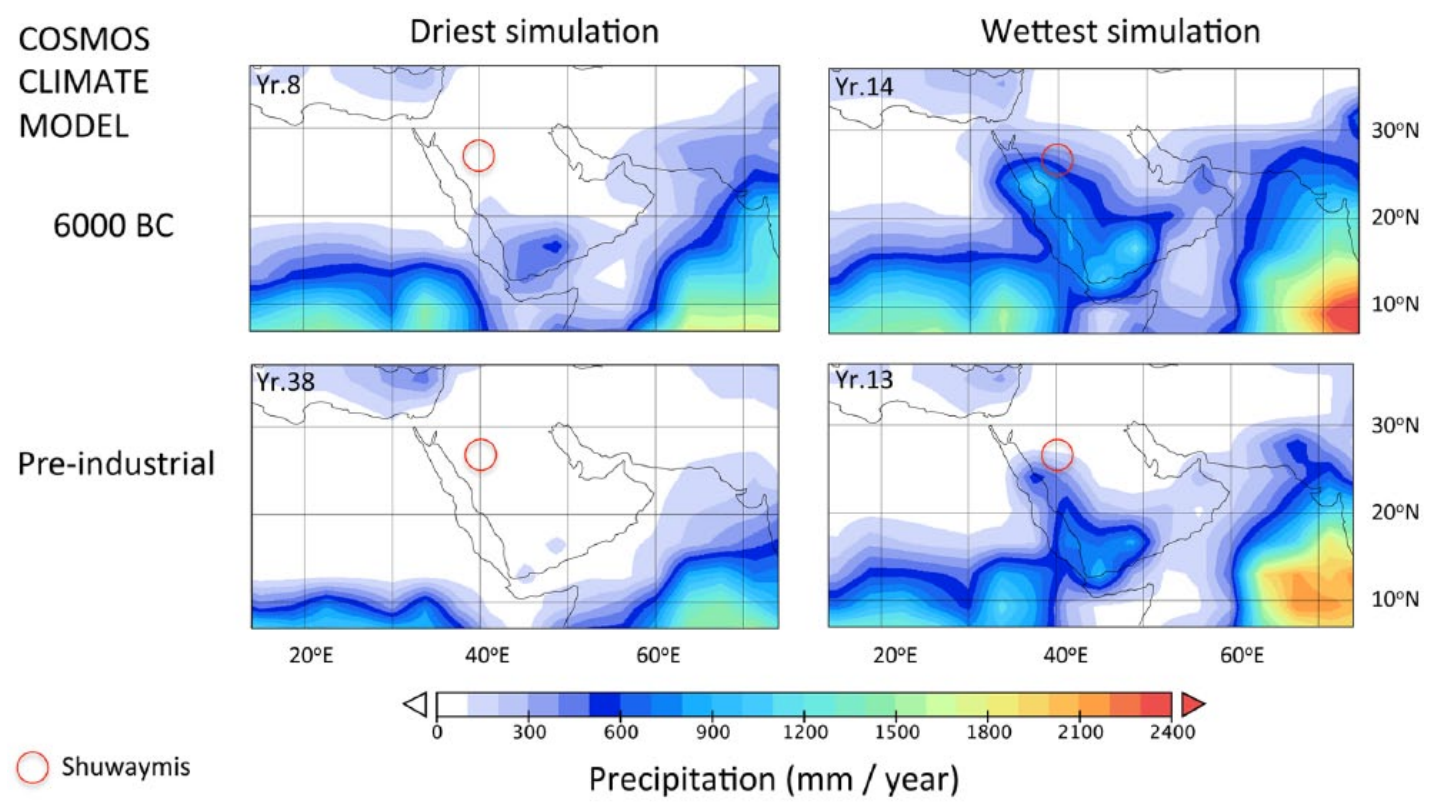

Figure 6. COSMOS simulated years of minimum and maximum rainfall for $6000 \mathrm{BC}$ and pre-industrial time slices. Rainfall levels peaked at Shuwaymis in year 15 of the 6000 BC climate simulation, with $420 \mathrm{~mm} / \mathrm{yr}$, and year 14 of the pre-industrial simulation, with $140 \mathrm{~mm} / \mathrm{yr}$.

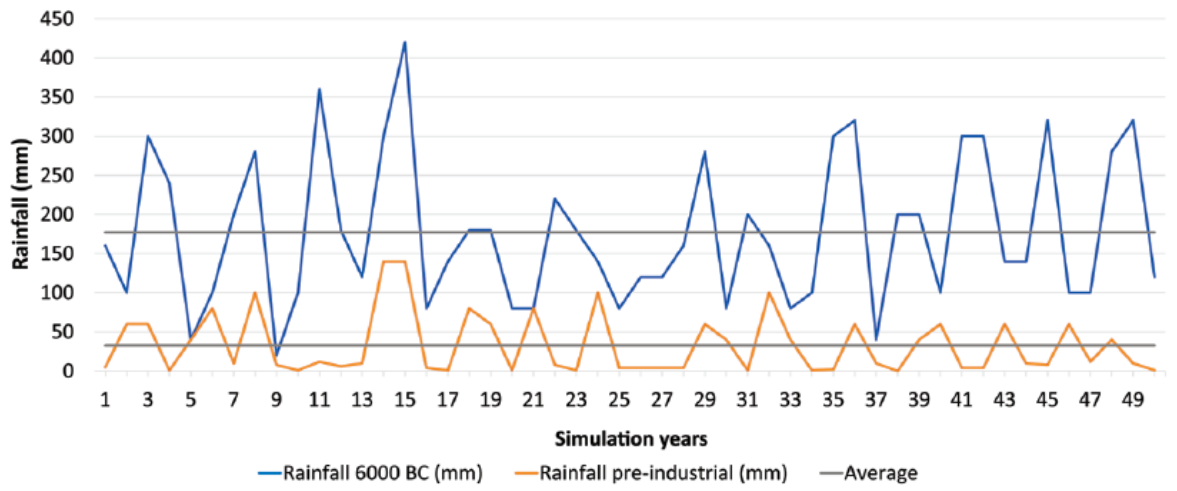

Figure 7. The 50-year time series of total annual rainfall $(\mathrm{mm})$ for $6000 \mathrm{BC}$ and pre-industrial climate simulation for Shuwaymis, derived from COSMOS. For $6000 \mathrm{BC}$, annual rainfall averages $177 \mathrm{~mm} / \mathrm{yr}$ over the 50 -year time series, with extreme values as high as $420 \mathrm{~mm}$ (year 15$)$ and as low as $20 \mathrm{~mm}$ (year 9). In contrast, annual rainfall values are considerably lower for pre-industrial climate, where they average $33 \mathrm{~mm}$ per year and range from $140 \mathrm{~mm}$ (year 14) to complete aridity (year 38). Average annual precipitation of both simulations is indicated with bold grey lines.

Both the HOL6 and PI climate simulations show that rainfall levels north of Shuwaymis rarely exceeded $200 \mathrm{~mm} / \mathrm{yr}$ (Figure 6), inferring the continued presence of the Saharo-Arabian arid belt during the Holocene humid phase. This pattern was also detected in a study of multiple climate simulations for the Pleistocene (Jennings et al., 2015) and suggests that the presence of the SaharoArabia desert belt persisted even during periods of increased rainfall.

\section{Discussion}

Although a quarter of the animal engravings recorded in Shuwaymis East can be attributed to the Holocene humid phase, when vegetation was abundant and lakes formed in areas that are arid today, the rock art shows an unexpectedly narrow species spectrum. While depictions of crocodiles, elephants and hippo have become iconic for the Green Sahara, evidence for wetter climate is much more subtle at Shuwaymis.

The stratigraphy of the engravings and the depiction of domesticates provide a broad chronological framework that allows a division into images created during the Holocene humid phase and animals represented after the onset of desert conditions. The engraved animal spectrum shows a marked contrast between the early and the late rock art phase, which mirror the environmental changes associated with the Holocene humid phase and the subsequent aridification of the area. Considering the small number of depicted animal species, the pictorial record of the early engraving phase at Shuwaymis contains an extraordinary range of carnivores. While leopard, cheetah, lion and hyena can survive in arid conditions, their simultaneous presence, suggested in the engravings, poses constraints on their habitats and requires a diverse landscape with different types of terrain and vegetation. In particular, leopards rely on dense vegetation and tend to cache their kill in trees to avoid kleptoparasitism from lions and hyena (Hayward et al., 2006a). Moreover, each of the large cat species specialises in a different size of prey, suggesting that equids and gazelle were abundant in the area around Shuwaymis (Figure 5). In contrast, gazelles are extremely rare in the rock art. This highlights the role of the 'artistic filter' in ecological reconstructions from rock art. While the presence of species in the rock art reflects the engraver's knowledge of the animal and therefore its presence in the landscape, the frequency of the depictions is unrelated to an abundance or scarcity of gazelles in the landscape. The engraving record and inferred abundance of gazelles mirrors the archaeological record in the Negev and the eastern Jordanian Badia, where a high frequency of ibex depictions is juxtaposed with an 
abundance of gazelles in the faunal record (Eisenberg-Degen and Rosen, 2013; Rollefson et al., 2008).

A comparison with the faunal record of the Arabian Peninsula shows that all larger animals that are thought to have been present in the area around Shuwaymis were also depicted in the rock art. The presence and absence of larger animals in the engravings are therefore a relatively accurate representation of the local ecosystem. In the context of the savannah-like environments indicated by the contemporaneous presence of several apex predators in the rock art and by palaeoenvironmental evidence (Crassard et al., 2013; Dinies et al., 2015; Engel et al., 2012; Hilbert et al., 2014), the absence of Levantine savannah species such as hartebeest and aurochs needs to be explained. In addition, caprine pastoralism is attested for the Negev and the Jordanian Badia from the PPNB onwards (Betts, 1993; Henry et al., 2003; Köhler-Rollefson, 1988; Martin, 1999; Rollefson et al., 2014). The absence of sheep and goat in the pictorial record is therefore highly unusual. Although the engravings show a clear cultural bias towards the depiction of larger animal species, where caprines are present, they are usually depicted in small numbers (Guagnin, 2014; Khan, 2007; Rollefson et al., 2008). Considering the sample size of Shuwaymis East, we would therefore expect at least a handful of depictions if caprines were herded alongside cattle.

The COSMOS climate simulations show that Shuwaymis was at the northern edge of the African Summer Monsoon rainfall regime (Figure 6). The region north of Shuwaymis remained substantially more arid, even during the Holocene humid period. This inferred aridity is also indicated by an absence of Holocene lake deposits observed in the dune fields of the Nefud (Rosenberg et al., 2013). It is therefore possible that an arid barrier remained in place, which restricted the dispersal of Levantine species into Arabia. The narrow species spectrum identified in the rock art and in the scarce faunal records, as well as the absence of caprines, may therefore be a result of an ecological barrier that largely remained in place during the Holocene humid period and restricted the movement of Levantine species. This challenges current Neolithisation models that assume a spread of Levantine herders via Mesopotamia and the Persian Gulf, or via the Red Sea coast and the Hejaz (Drechsler, 2009; Uerpmann et al., 2009) and indicates that the Neolithisation of the Arabian Peninsula may have been more complex (Charpentier and Crassard, 2013; Crassard and Drechsler, 2013). However, lithic evidence from Epipalaeolithic and PPN sites in the oasis of Jubbah (Crassard et al., 2013; Hilbert et al., 2014) suggests that links with the Levant did exist in some form. Instead, rainfall regimes simulated in climate modelling suggest that Shuwaymis was ecologically connected with the southwest of the Arabian Peninsula. The long-term survival of carnivores indicates that substantial metapopulations were available in the landscapes around Shuwaymis, enabling immigration and emigration of individuals. Based on the results of the HOL6 climate simulation, large carnivores are likely to have found suitable habitats in the areas that were reached by the monsoon. However, smaller groups of animals may also have survived in oases such as Jubbah and Tayma.

Despite the evident presence of a Holocene humid phase at Shuwaymis, there is some indication in the rock art that the environment was marginal and climatic amelioration may have been short lived. Based on early dates for domestic herds in the rest of the Arabian Peninsula, domestic cattle were probably introduced around $6000 \mathrm{BC}$ and could have been present until the onset of severe arid conditions around 4000 BC. Only 104 cattle depictions were recorded at Shuwaymis East, suggesting that occupation was either sparse and intermittent or short lived. The similarity in the cattle representations suggests that the majority was created shortly after the shift to a herding economy. A depiction of a starving ox (Figure 8) may reflect the end of humid conditions at Shuwaymis or that droughts were common in this

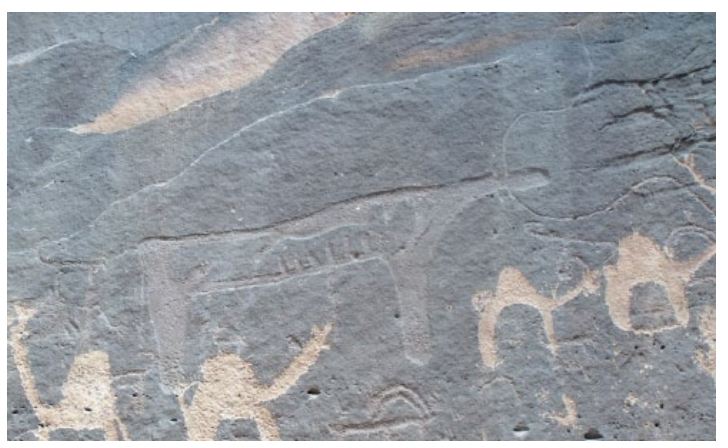

Figure 8. Engraving of an ox with ribs clearly visible.A number of camels were later superimposed onto the scene. Panel 103A, Shuwaymis East.

marginal environment (see also Figure 7). For about three millennia, rock art creation at Shuwaymis ceased and hunters may only have visited the area sporadically, occasionally engraving an image of an ibex, or possibly of camels (Figure 2). Shuwaymis only began to be re-visited once the domestication of camel opened up access to landscapes that had become too arid to sustain other forms of subsistence. Again, occupation at Shuwaymis appears to have been short lived. Only 31 depictions of horses were identified, suggesting that the area was largely abandoned shortly after the introduction of domestic horses. This is also evident in the low number of inscriptions. While writing was widespread among sedentary and nomadic societies, and tens of thousands of inscriptions have been recorded on rock surfaces across the northwest of the Arabia (Online Corpus of the Inscriptions of Ancient North Arabia (OCIANA), 2015), only 11 inscriptions were recorded at Shuwaymis. It appears that the location of Shuwaymis, surrounded by ancient lava fields to the south and east, and the Nefud desert to the north, was unsuitable for human occupation for most of the Holocene.

Notwithstanding some obvious caveats that influence rock art research, namely, a paucity of direct dating methods and a cultural filter that determined which animals were chosen for depictions, the rock art of Shuwaymis clearly holds a range of environmental information. The combined approach of a zoological identification of animal engravings, carnivore habitat and prey biomass estimates, and climate modelling enabled a broad reconstruction of Holocene landscapes and their ecological connectivity. In a region where excavated archaeological sites and analysis of faunal remains are still scarce, the rock art can provide a valuable contribution to our knowledge of prehistoric animal populations, and human occupation of Holocene landscapes. Moreover, the rock art is a direct reflection of the impact humans and their domestic herds had on the local landscape. Hunting and herding would have put additional pressure on the local vegetation and wildlife even in remote areas such as Shuwaymis, at a considerable distance from known settlements and oases. However, our results also raise further questions. How can we reconcile an environment in which carnivores and prey were abundant with a possible pattern of short lived or intermittent human occupation? This will need to be addressed in further research focussing on the palaeoenvironment and archaeology of this extraordinary UNESCO World Heritage site. Our analyses clearly show that the rock art of Shuwaymis contains important evidence on the Holocene wildlife and vegetation in the area and needs to be integrated into archaeological and palaeoenvironmental research.

\section{Acknowledgements}

We thank His Royal Highness Prince Sultan bin Salman, President of the Saudi Commission for Tourism and National Heritage, and Professor Ali Ghabban, Vice President, for permission to 
carry out the fieldwork at Shuwaymis. The fieldwork at Shuwaymis could not have been done without the support of our Saudi colleagues, especially Jamal Omar, Abdullah Alsharekh and Abdulaziz al Omari.

\section{Funding}

The Palaeodeserts rock art research was funded by the European Research Council (no. 295719, to MDP).

\section{References}

Al-Saud A and Khan M (2005) Rock art and Epigraphic Survey of Jubbah and Shuwaymis, Northern Saudi Arabia (2003/1426H). Atlal 19: 49-54.

Barnett R, Yamaguchi N, Shapiro B et al. (2014) Revealing the maternal demographic history of Panthera leo using ancient DNA and a spatially explicit genealogical analysis. BMC Evolutionary Biology 14: 70.

Barth H (1857) Travels and Discoveries in North and Central Africa: Being a Journal of an Expedition Undertaken Under the Auspices of H.B.M's Government in the Years 1849-1855, vol. 1. London: Longman, Brown, Green, Longmans, \& Roberts.

Bednarik RG and Khan M (2002) The Saudi Arabian rock art mission of November 2001. Atlal 17: 75-99.

Berger AL (1978) Long-term variations of daily insolation and quaternary climatic changes. Journal of Atmospheric Sciences 35: 2362-2367.

Betts A (1993) The Neolithic sequence in the East Jordan Badia: A preliminary overview. Paléorient 19(1): 43-53.

Burns SJ, Fleitmann D, Matter A et al. (2001) Speleothem evidence from Oman for continental pluvial events during interglacial periods. Geology 29: 623-626.

Carbone C and Gittleman JL (2002) A common rule for the scaling of carnivore density. Science 295: 2273-2276.

Charpentier V and Crassard R (2013) Back to Fasad ... and the PPNB controversy. Questioning a Levantine origin for Arabian Early Holocene projectile points technology. Arabian Archaeology and Epigraphy 24: 28-36.

Clements H, Tambling C, Hayward M et al. (2014) An objective approach to determining the weight ranges of prey preferred by and accessible to the five large African carnivores. PLoS ONE 9: e101054.

Cooper RG, Mahrose KMA, Horbańczuk JO et al. (2009) The wild ostrich (Struthio camelus): A review. Tropical Animal Health and Production 41: 1669-1678.

Crassard R and Drechsler P (2013) Towards new paradigms: Multiple pathways for the Arabian Neolithic. Arabian Archaeology and Epigraphy 24: 3-8.

Crassard R, Petraglia MD, Parker AG et al. (2013) Beyond the Levant: First evidence of a pre-pottery neolithic incursion into the Nefud Desert, Saudi Arabia. PLoS ONE 8: e68061.

Cremaschi M (1998) Late quaternary geological evidence for environmental changes in south-western Fezzan (Libyan Sahara). In: Cremaschi M and Di Lernia S (eds) Wadi Teshuinat - Palaeoenvironment and Prehistory in South-Western Fezzan (Libyan Sahara). Milano: CIRSA, pp. 13-47.

Curci A, Carletti M and Tosi M (2014) The camel remains from site HD-6 (Ra's al-Hadd, Sultanate of Oman): An opportunity for a critical review of dromedary findings in eastern Arabia. Anthropozoolgica 49(2): 207-222.

deMenocal PB and Tierney JE (2012) Green Sahara: African humid periods paced by earth's orbital changes. Nature Education Knowledge 3(10): 12.

Dinies M, Plessen B, Neef R et al. (2015) When the desert was green: Grassland expansion during the early Holocene in northwestern Arabia. Quaternary International 382: 293-302.
Drechsler P (2007) The Neolithic dispersal into Arabia. Proceedings of the Seminar for Arabian Studies 37: 93-109.

Drechsler P (2009) The Dispersal of the Neolithic Over the Arabian Peninsula. Oxford: BAR International Series 1969.

Eichmann R, Schaudig H and Hausleiter A (2006) Archaeology and epigraphy at Tayma (Saudi Arabia). Arabian Archaeology and Epigraphy 17(2): 163-176.

Eisenberg-Degen D and Rosen SA (2013) Chronological trends in Negev rock art: The Har Michia petroglyphs as a test case. Arts 2: 225-252.

Engel M, Brückner H, Pint A et al. (2012) The early Holocene humid period in NW Saudi Arabia - Sediments, microfossils and palaeo-hydrological modelling. Quaternary International 266: $131-141$.

Estes RD (1991) The Behaviour Guide to African Mammals. Berkeley: University of California Press.

Fedele GF (2008) Wadi at-Tayyilah 3, a Neolithic and PreNeolithic occupation on the eastern Yemen Plateau, and its archaeofaunal information. Proceedings of the Seminar for Arabian Studies 38: 153-172.

Fleitmann D, Burns SJ, Mangini A et al. (2007) Holocene ITCZ and Indian monsoon dynamics recorded in stalagmites from Oman and Yemen (Socotra). Quaternary Science Reviews 26: $170-188$.

Fleitmann D, Burns SJ, Neff U et al. (2003) Changing moisture sources over the last 330,000years in Northern Oman from fluid-inclusion evidence in speleothems. Quaternary Research 60(2): 223-232.

Fleitmann D, Cheng H, Badertscher S et al. (2009) Timing and climatic impact of Greenland interstadials recorded in stalagmites from northern Turkey. Geophysical Research Letters 36. Available at: http://dx.doi.org/10.1029/2009GL040050.

Förster F (2007) The Abu Ballas Trail: A Pharaonic donkey-caravan route in the Libyan Desert (SW-Egypt). In: Bubenzer O, Bolten A and Darius F (eds) Atlas of Cultural and Environmental Change in Arid Africa. Köln: Heinrich-Barth-Institut, pp. $130-133$.

Garrard AN, Harvey CPD and Switsur VR (1981) Environment and settlement during the Upper Pleistocene and Holocene at Jubba in the Great Nefud, Northern Arabia. Atlal 5: 137-148.

Gasperetti J, Harrison DL and Büttiker W (1985) The Carnivora of Arabia. In: Büttiker W, Krupp F, Mahnert V et al. (eds) Fauna of Saudi Arabia, vol. 7. Basel: Karger Libri AG, pp. 397-461.

Grigson C (2012) Camels, copper and donkeys in the Early Iron Age of the southern Levant: Timna revisited. Levant 44: 82100.

Grinder MI, Krausman PR and Hoffmann RS (2006) Equus asinus. Mammalian Species 794: 1-9.

Groucutt HS and Petraglia MD (2012) The prehistory of the Arabian Peninsula: Deserts, dispersals and demography. Evolutionary Anthropology 21: 113-125.

Guagnin M (2014) Animal engravings in the central Sahara: A proxy of a proxy. Environmental Archaeology 20: 52-65.

Guagnin M, Jennings R, Clark-Balzan L et al. (2015) Hunters and herders: Exploring the Neolithic transition in the rock art of Shuwaymis, Saudi Arabia. Archaeological Research in Asia 4: 3-16.

Harrison D and Bates P (1991) The Mammals of Arabia. Sevenoaks: Harrison Zoological Museum Publication.

Hatton I, McCann K, Fryxell J et al. (2015) The predator-prey power law: Biomass scaling across terrestrial and aquatic biomes. Science 349: 6252.

Hausleiter A (2010) The oasis of Tayma. In: Al-Ghabban AI, André-Salvini B, Demenage F et al. (eds) Roads of Arabia: Archaeology and History of the Kingdom of Saudi Arabia. Paris: Museé du Louvre, pp. 218-261. 
Hayward MW and Kerley GIH (2005) Prey preferences of the lion (Panthera leo). Journal of the Zoological Society of London 267: 309-322.

Hayward MW, O'Brien J and Kerley GIH (2007) Carrying capacity of large African predators: Predictions and tests. Biological Conservation 139: 219-229.

Hayward MW, Henschel P, O'Brian J et al. (2006a) Prey preferences of the leopard (Panthera pardus). Journal of Zoology 270: 298-313.

Hayward MW, Hofmeyr M, O'Brien J et al. (2006b) Prey preferences of the cheetah (Acinonyx jubatus) (Felidae: Carnivora): Morphological limitations of the need to capture rapidly consumable prey before kleptoparasites arrive? Journal of Zoology 270: 615-627.

Henry DO, Cordova C, White JJ et al. (2003) The early Neolithic site of Ayn Abū Nukhayla, Southern Jordan. Bulletin of the American Schools of Oriental Research 330: 1-30.

Hilbert Y, White T, Parton A et al. (2014) Epipalaeolithic occupation and palaeoenvironments of the southern Nefud desert, Saudi Arabia, during the Terminal Pleistocene and Early Holocene. Journal of Archaeological Science 50: 460-474.

Horsfield G, Horsfield A and Glueck N (1933) Prehistoric rockdrawings in Transjordan. American Journal of Archaeology 37: 381-386.

IUCN (2015) The IUCN Red List of Threatened Species. Available at: http://www.iucnredlist.org (accessed 21 December 2015).

Jennings R, Parton A, Groucutt HS et al. (2014) High-resolution geospatial surveying techniques provide new insights into rock-art landscapes at Shuwaymis, Saudi Arabia. Arabian Archaeology and Epigraphy 25: 1-21.

Jennings RP, Singarayer J, Stone EJ et al. (2015) The greening of Arabia: Multiple opportunities for human occupation of the Arabian Peninsula during the Late Pleistocene inferred from an ensemble of climate model simulations. Quaternary International 382: 181-199.

Khan M (2007) Rock Art of Arabia across Twelve Thousand Years. Riyadh: Deputy Ministry of Antiquities and Museums.

Kimura B, Marshall F, Beja-Pereira A et al. (2013) Donkey domestication. African Archaeological Review 30: 83-95.

Kingdon J (1997) The Kingdon Field Guide to African Mammals. London: Academic Press.

Köhler-Rollefson I (1988) The aftermath of the Levantine Neolithic revolution in the light of ecological and ethnographic evidence. Paléorient 14(1): 87-93.

Le Quellec JL (1998) Art rupestre et préhistoire du Sahara: Le Messak libyen. Paris: Payot and Rivages.

Lézine AM, Hély C, Grenier C et al. (2011) Sahara and Sahel vulnerability to climate changes, lessons from Holocene hydrological data. Quaternary Science Reviews 30(21-22): 3001-3012.

Lézine AM, Tiercelin JJ, Robert C et al. (2007) Centennial to millennial-scale variability of the Indian monsoon during the early Holocene from a sediment, pollen and isotope record from the desert of Yemen. Palaeogeography, Palaeoclimatology, Palaeoecology 243: 235-249.

Lutz R and Lutz G (1995) The Secret of the Desert. Innsbruck: Golf Verlag.

McCorriston J and Martin L (2009) Southern Arabia's early pastoral population history: Some recent evidence. In: Petraglia $\mathrm{M}$ and Rose J (eds) The Evolution of Human Populations in Arabia - Paleoenvironments, Prehistory and Genetics. Dordrecht: Springer, pp. 237-250.

Macdonald MCA (2010) Ancient Arabia and the written word. In: Macdonald MCA (ed.) The Development of Arabic as a Written Language (Supplement to the Proceedings of the Seminar for Arabian Studies 40). Oxford: Archaeopress, pp. 5-28.
Macdonald MCA (2012) Goddesses, dancing girls or cheerleaders? Perceptions of the divine and the female form in the rock art of pre-Islamic North Arabia. In: Sachet I and Robin CJ (eds) Dieux et déesses d'Arabie. Images et representations. Actes de la table ronde tenue au Collège de France (Paris) les 1er et 2 octobre 2007. Paris: De Boccard, pp. 261-297.

Magee P (2014) The Archaeology of Prehistoric Arabia: Adaptation and Social Formation from the Neolithic to the Iron Age. New York: Cambridge University Press.

Maraqten M (2015) Hunting in pre-Islamic Arabia in light of the epigraphic evidence. Arabian Archaeology and Epigraphy 26: $208-234$

Martin L (1999) Mammal remains from the eastern Jordanian Neolithic, and the nature of caprine herding in the steppe. Paléorient 25(2): 87-104.

Mattingly D (2006) The Garamantes: The first Libyan state. In: Mattingly D, McLaren S, Savage E et al. (eds) The Libyan Desert: Natural Resources and Cultural Heritage. London: The Society for Libyan Studies, pp. 189-204.

Muzzolini A (1992) Dating the earliest central Saharan rock art. In: Friedman R and Adams B (eds) The Followers of Horus: Studies Dedicated to Michael Allen Hoffman. Oxford: Oxbow Books, pp. 148-153.

Newton LS and Zarins J (2000) Aspects of Bronze Age art of southern Arabia: The pictorial landscape and its relation to economic and socio-political status. Arabian Archaeology and Epigraphy 11: 154-179.

Olsen SL and Bryant RT (2013) Stories in the Rocks: Exploring Saudi Arabian Rock Art. Pittsburgh, PA: Carnegie Museum of Natural History.

Online Corpus of the Inscriptions of Ancient North Arabia (OCIANA) (2015) Available at: http://krc.orient.ox.ac.uk/ociana/ index.php (accessed 21 December 2015).

Otte MJ and Chilonda P (2002) Cattle and Small Ruminant Production Systems in Sub-Saharan Africa. A Systematic Review. Rome: Food and Agriculture Organization of the United Nations.

Parker AG, Goudie AS, Stokes S et al. (2006) A record of Holocene Climate Change from lake geochemical analyses in southeastern Arabia. Quaternary Research 66: 465-476.

Parr PJ, Zarins J, Ibrahim M et al. (1978) Preliminary report on the second phase of the Northern Province Survey 1397/1977. Atlal 2: 29-50.

Parton A, White TS, Parker AG et al. (2015) Orbital-scale climate variability in Arabia as a potential motor for human dispersals. Quaternary International 382: 82-97.

Petraglia MD and Rose JI (2009) The Evolution of Human Populations in Arabia: Paleoenvironments, Prehistory and Genetics. Dordrecht: Springer.

Petraglia MD, Parton A, Groucutt HS et al. (2015) Green Arabia: Human prehistory at the crossroads of continents. Quaternary International 382: 1-7.

Pfeiffer M and Lohmann G (in press) Greenland Ice Sheet influence on Last Interglacial climate: Global sensitivity studies performed with an atmosphere-ocean general circulation model. Climate of the Past.

Preston GW, Parker AG, Walkington H et al. (2012) From nomadic herder-hunters to sedentary farmers: The relationship between climate change and ancient subsistence strategies in south-eastern Arabia. Journal of Arid Environments 86: $122-130$

Reed D, O'Grady J, Brook B et al. (2003) Estimates of minimum viable population sizes for vertebrates and factors influencing those estimates. Biological Conservation 113: 23-34.

Robinson TJ and Matthee CA (1999) Molecular genetic relationships of the extinct ostrich, Struthio camelus syriacus: Consequences for ostrich introductions into Saudi Arabia. Animal Conservation 2: 165-171. 
Rollefson G, Rowan Y and Wasse A (2014) The Late Neolithic colonization of the Eastern Badja of Jordan. Levant 46(2): $1-17$.

Rollefson GO, Wasse A and Rowan Y (2008) Images of the environment: Rock art and the exploitation of the Jordanian Badiah. Journal of Epigraphy and Rock Drawings 2: 17-51.

Rosenberg TM, Preusser F, Risberg J et al. (2013) Middle and Late Pleistocene humid periods recorded in palaeolake deposits of the Nafud desert, Saudi Arabia. Quaternary Science Reviews 70: 109-123.

Serjeant RB (1976) South Arabian Hunt. London: LUZAC.

Smith A (2005) African Herders: Emergence of Pastoral Traditions. Oxford: AltaMira Press.

Stepanek C and Lohmann G (2012) Modelling mid-Pliocene climate with COSMOS. Geoscientific Model Development 5: 1221-1243.

Uerpmann HP (1987) The Ancient Distribution of Ungulate Mammals in the Middle East (Beihefte zum Tübinger Atlas des Vorderen Orient, Reihe A (Naturwissenschaften) 27). Wiesbaden: Dr. Ludwig Reichert Verlag.
Uerpmann HP, Potts D and Uerpmann M (2009) Holocene (re)occupation of eastern Arabia. In: Petraglia MD and Rose JI (eds) Evolution of Human Populations in Arabia: Palaeoenvironments, Prehistory and Genetics. Dordrecht: Springer, pp. 205-214.

Uerpmann M and Uerpmann HP (2012) Archaeozoology of camels in South-Eastern Arabia. In: Knoll EM and Burger P (eds) Camels in Asia and North Africa: Interdisciplinary Perspectives on their Past and Present Significance. Wien: Verlag der Österreichischen Akademie der Wissenschaften, pp. 109-122.

Vernet R (1995) Climats Anciens du Nord de l'Afrique. Paris: L'Harmattan.

Watts H and Holekamp K (2007) Hyena societies. Current Biology 17: R657-R660.

Wildscreen Arkive (2015) Available at: http://www.arkive.org/ mountain-gazelle/gazella-gazella/ (accessed 21 December 2015).

Winney BJ, Hammond RL, Macasero W et al. (2004) Crossing the Red Sea: Phylogeography of the hamadryas baboon, Papio hamadryas hamadryas. Molecular Ecology 13: 2819-2827. 